ROCZNIKI TEOLOGICZNE

Volume LXV, issue 9 - 2018

Englis h version

DOI: http://dx.doi.org/10.18290/rt.2018.65.9-5en

REV. JACENTY MASTEJ

\title{
THE ACHIEVEMENTS OF THE LUBLIN SCHOOL OF FUNDAMENTAL THEOLOGY IN THE FIELD OF CHRISTOLOGY
}

\begin{abstract}
The aim of this article is to show the achievements of the Lublin School of Fundamental Theology in the field of Christology. The first part of this article presents a short outline of Christological research, at the same time focusing on the most important research publications of the Lublin center in the field of Christology. The second part discusses the essential features of the Lublin School of Fundamental Christology.
\end{abstract}

Keywords: Jesus Christ, Christology, the Lublin School of Fundamental Theology, messianic consciousness, miracles, cross, the Resurrection, faith, the credibility of Christianity.

The $100^{\text {th }}$ anniversary of the founding of the John Paul II Catholic University of Lublin is an opportunity to present the academic achievements of the Lublin School of Fundamental Theology. The beginning of research in fundamental theology, including Christology, dates back to the beginnings of the Catholic University of Lublin and is associated with the establishment of the Chair of Fundamental Theology, which was created at the first meeting of CUL's academic senate in 1918 and entrusted to Rev. Prof. Piotr Kremer. However, the start of the Lublin School of Fundamental Theology goes back to Rev. Prof. Edward Kopeć, and Rev. Marian Rusecki and his students contributed to its development. ${ }^{1}$

Rev. Dr. Hab. Jacenty Mastej, KUL professor, is the head of the Department of Fundamental Christology and Ecclesiology; Institute of Fundamental Theology, John Paul II Catholic University of Lublin, Al. Racławickie 14, 20-950 Lublin; lecturer in fundamental theology at the Priestly Formation Seminary in Rzeszów; address for correspondence: e-mail jmastej@ kul.pl

${ }^{1}$ Stanisław NAGY, "Sekcja Teologii Fundamentalnej," in Księga pamiatkowa w 75-lecie Katolickiego Uniwersytetu Lubelskiego. Wktad w kulture polska w latach 1968-1993, ed. Marian Rusecki (Lublin: Wydawnictwo KUL, 1994), 188; Krzysztof KAUCHA, "Wiarygodność i wiara 
This article will show the achievements of the Lublin School of Fundamental Theology in the field of Christology. The article's structure consists of two parts. The first part presents an outline of Christological research, highlighting the most important academic research publications of the Lublin center in the field of Christology. In the second part, we undertake a short description of the essential features of Lublin's Fundamental Christology. ${ }^{2}$

\section{CHRISTOLOGICAL RESEARCH STUDIES IN THE LUBLIN SCHOOL OF FUNDAMENTAL THEOLOGY}

Within the framework of Christology practiced at the Institute of Fundamental Theology, the following areas can be distinguished: the historicity of Jesus of Nazareth (1.1.); Messianic consciousness: the divine dignity of Jesus (1.2.); theology of miracles (1.3.); staurology and resurrection theology (1.4); the faith and credibility of Christianity (1.5.).

\subsection{JESUS OF NAZARETH'S HISTORICITY}

The basic issue for fundamental Christology is to demonstrate the real existence or historicity of the Person of Jesus of Nazareth. The actual questioning of his earthly existence would undermine the credibility of Christianity as a revealed and salvific religion, for Christianity would then have the same value as mythical religions. Hence, within the Lublin School of Fundamental Theology, research is conducted to present reliable historical (direct and indirect) evidence, both Christian and non-Christian, including Jewish and Roman sources. The results of archaeological research and indepth knowledge of the religious, social, cultural, geographical and historical conditions, including the times in which Jesus of Nazareth lived, are also of great importance.

w ujęciu lubelskiej szkoły teologii fundamentalnej," in Wiara-wiarygodność, ed. Damian Wąsek (Kraków: Wydawnictwo Naukowe UPJPII w Krakowie, 2014), 51-60.

${ }^{2}$ In this study, Christological issues related to the unique character of Christianity were deliberately omitted, because in the Lublin School of Fundamental Theology, they are mainly taken up within the framework of theology of religion, which is why they are the subject of a separate field. Issues concerning divine revelation and fundamental Christology's methodology are also the subjects of separate research studies. 
In the Lublin theological center, apologetics on theories that question the historical existence of Jesus is carried out. The above issues are the subject of research publications, among others by Rev. E. Kopeć, ${ }^{3}$ Rev. M. Rusecki, and Fr. I.S. Ledwon. ${ }^{4}$ The issue of the historicity of Jesus Christ finds a comprehensive entry in the Lexicon of Fundamental Theology in many aspects. It discusses the time of Jesus' birth, his human appearance, Christian testimonies, non-Christian testimonies (Jewish, Roman, Islamic) and contemporary controversies. ${ }^{5}$

\subsection{MESSIANIC CONSCIOUSNESS. THE DIVINE DIGNITY OF JESUS}

The key questions posed in the context of Fundamental Christology concern the person of Jesus of Nazareth. Who did he consider himself to be and how did he justify the claims he made? What was Jesus like in his earthly life, his thinking, desires, and actions? How did he understand himself and what did his relationship with God, people and the world look like? Was he aware of his salvific mission? Did he know that he was the Messiah, the Son of God? These questions concern the consciousness of Jesus of Nazareth.

Traditional apologetic Christology, referring to the messianic consciousness of Jesus, focused mainly on the discussion of three Christological titles: the Messiah, Son of Man and Son of God. However, the justification of his divine dignity was usually reduced to three arguments: scriptural, thaumaturgical and the resurrection, where the resurrection was considered the greatest reason. Such an approach to the discussed issue is visible in the academic output of Rev. E. Kopeć. ${ }^{6}$

Contemporary Fundamental Christology in Lublin presents the issue of the messianic consciousness of Jesus and his divine dignity in many aspects.

\footnotetext{
${ }^{3}$ Edward Kopeć, Teologia fundamentalna (Lublin: RW KUL, 1976 ${ }^{3}$ ), 97-133; Edward KoPEĆ, "Historyczne istnienie Jezusa Chrystusa," in Jezus Chrystus. Historia i Tajemnica, ed. Wincenty Granat, Edward Kopeć (Lublin: TN KUL, 1982), 73-99.

${ }^{4}$ Ireneusz S. LedwoŃ, Historyczność Jezusa Chrystusa. Skrypt dla doktorantów (Lublin: Wydawnictwo KUL, 2010).

${ }^{5}$ Marian RuSECKI, Jarosław PoPŁAwski, Jacenty MasteJ, "Historyczność Jezusa Chrystusa," in Leksykon Teologii Fundamentalnej, ed. Marian Rusecki, Krzysztof Kaucha, Ireneusz S. Ledwoń, Jacenty Mastej (Lublin-Kraków: Wydawnictwo M 2002 ${ }^{6}$ ), 504-521; E. KoPEć, Teologia fundamentalna, 133-173.

${ }^{6}$ Kopé́, Teologia fundamentalna, 133-173.
} 
Above all, we emphasize that the messianic consciousness of Jesus of Nazareth originates in his Divine and human subjectivity. Jesus knows who he is and expresses his consciousness throughout his earthly life in both direct and indirect ways. Jesus' knowledge of his messianic consciousness and divine dignity demand paying attention to his unique relationship with himself, to God the Father, to people and to the world around him.

An in-depth study of these relationships is possible thanks to the Gospels that include the authentic statements of Jesus, the descriptions of the events of his life and the testimonies of those who recognize who he is and believe in him. Lublin's Christology also points to the need to discuss many more of his Christological titles, because there are about 70 such dignifying terms concerning the person of Jesus in the New Testament. It is necessary to emphasize their meaning (and understanding) in the context of the Old Testament, the earthly life of Jesus, and especially the Paschal events. On the other hand, in presenting the scriptural argument, it is important to concentrate not so much on the literal fulfillment of the prophesy as on the beauty and logic of the history of Revelation, whose fullness is Jesus Christ. The themes of the messianic and divine dignity of Jesus are presented in publications, among others by M. Rusecki ${ }^{7}$ and Rev. J. Mastej. ${ }^{8}$

This issue was also the subject of doctoral dissertations written under the direction of Rev. M. Rusecki by Rev. Ryszard Tomczak, The Problem of the Messianic Identity of Jesus in Mt 11, 2-6 and Luke 7,18-23 in the Light of Contemporary Theological Literature (defense in 1989) and by Rev. Janusz Wiśniewski, The Pro-Existence of Jesus of Nazareth, an Expression of Divine Consciousness in Polish-Language Post-Vatican Theological Literature (defense in 2006).

\subsection{THE THEOLOGY OF MIRACLES}

The precursor of the post-conciliar view on the issue of miracles in the Lublin center was Rev. E. Kopeć. He addressed the following issues in his

\footnotetext{
${ }^{7}$ Marian RuSECKI, "Za kogo uważał się Jezus? Mesjańska świadomość Jezusa," in Być chrześcijaninem dziś. Teologia dla szkót średnich, ed. Marian Rusecki (Lublin: RW KUL, 1992), 146-151; Marian RUSECKI, "Wiarygodność posłannictwa Jezusa Chrystusa," in Jezus Chrystus jedyny i uniwersalny Zbawiciel. Sympozjum, ed. Zbigniew Morawiec (Kraków: Wydawnictwo Księży Sercanów, 2001), 19-35; Marian RuSECKI, Traktat o Objawieniu (Kraków: Wydawnictwo Księży Sercanów, 2007), 258-381.

${ }^{8}$ Jacenty MASTEJ, "Czy Jezus wiedział, że jest Mesjaszem? Mesjańska świadomość Jezusa z Nazaretu," Lumen Bibliae 4 (2014): 117-134.
} 
publications: the issue of miracles in contemporary apologetics, ${ }^{9}$ the motivational value of miracles ${ }^{10}$ and identifying miracles. ${ }^{11}$ However, the theology of miracles in Poland flourished in the $20^{\text {th }}$ century thanks to Rev. M. Rusecki. The main part of his achievements concern the issue of miracles. This Lublin professor published seven books on the subject of miracles: Wierzcie moim dziełom. Funkcja motywacyjna cudu w teologii XX wieku (Katowice: Księgarnia św. Jacka, 1988), Cud w myśli chrześcijańskiej (Lublin: TN KUL, 1991), Cud w chrześcijaństwie (Lublin: TN KUL, 1996), Funkcje cudu (Sandomierz- -Lublin: Wydawnictwo Diecezjalne, 1997); Gottes Wirken in der Welt. Dimensionen und Funktionen des biblischen Wunderbegriffs (Frankfurt am Main: Peter Lang Europäischer Verlag der Wissenschaften, 2001), Problem cudu $w$ religiach pozachrześcijańskich (Lublin: TN KUL, 2001), Traktat o cudzie (Lublin: Komitet Nauk Teologicznych PAN - Wydawnictwo KUL, 2006).

The last publication is a holistic and unique study of miraculous issues in Polish theology. Rev. M. Rusecki devoted over a dozen research articles to the discussed issue. ${ }^{12}$ This innovative undertaking of issues concerning

\footnotetext{
${ }^{9}$ Edward KoPEć, "Problematyka cudu w apologetyce współczesnej," in Pod tchnieniem Ducha Świętego, ed. Marian Finke (Poznań-Warszawa-Lublin: Księgarnia św. Wojciecha, 1964), 267-282.

${ }^{10}$ Edward Kopeć, "Walor motywacyjny cudów," Roczniki Teologiczno-Kanoniczne 19, no 2 (1972): 99-110; Edward KopEć, "Über den motivationswert des Wunders," Collectanea Theologica 46, f. spec. (1976): 45-57.

${ }^{11}$ Edward Kopeć, "Problematyka rozpoznania cudu," Roczniki Teologiczno-Kanoniczne 13, no 2 (1966): 5-22; Kopé́, Teologia fundamentalna, 77-94.

${ }^{12}$ Marian RUSECKI, "Funkcja argumentacyjna cudu w pierwszych trzech wiekach Kościoła," Roczniki Teologiczno-Kanoniczne 26, no 2 (1979): 29-40; Marian RUSECKI, "Rola motywacyjna cudu według św. Tomasza z Akwinu,” Roczniki Teologiczno-Kanoniczne 26, no 3 (1979): 93-106; Marian RUSECKI, "Funkcje cudu jako znaku," Roczniki Teologiczno-Kanoniczne 27, no 2 (1980): 51-70; Marian RuSECKI, "Cud jako znak i symbol," Roczniki Teologiczno-Kanoniczne 28, no 2 (1981): 79-95; Marian RuSECKI, “Cud a słowo," Roczniki Teologiczno-Kanoniczne 30, no 6 (1983): 229-238; Marian RUSECKI, "Pedagogiczne funkcje cudu według św. Grzegorza Wielkiego,” Roczniki Teologiczno-Kanoniczne 30, no 2 (1983): 33-49; Marian RUSECKI, "Świętego Augustyna teologiczne rozumienie cudu i jego funkcji," Roczniki Teologiczno-Kanoniczne 31, no 2 (1984): 107-124; Marian RUSECKI, "Ewolucja funkcji motywacyjnej cudu w genezie aktu wiary," Roczniki TeologicznoKanoniczne 33, no 2 (1986): 95-120; Marian RUSECKI, "Teofanijny charakter cudu," Collectanea Theologica 57, no 4 (1987): 39-54; Marian RUSECKI, "Cud w apologetyce F.D.E. Schleiermachera," Roczniki Teologiczno-Kanoniczne 35, no 2 (1988): 83-94; Marian RUSECKI, "Problem dowodzenia z cudu w drugiej szkole augustyńskiej,” Roczniki Teologiczno-Kanoniczne 35, no 2 (1988): 65-82; Marian RUSECKI, "Soteryczny wymiar cudu," Collectanea Theologica 58, no 1 (1988): 71-87; Marian RUSECKI, "Cud w apologetycznej myśli Błażeja Pascala," Roczniki Teologiczno-Kanoniczne 37, no 2 (1990): 5-20; Marian RUSECKI, “J.H. Newmana religijne rozumienie cudu," in Historia i Logos. Księga pamiątkowa ku czci Ks. prof. Czestawa S. Bartnika, ed. Kazimierz Macheta, Krzysztof Góźdź, Mirosław Kowalczyk (Lublin: RW KUL, 1991), 116-129; Marian RUSECKI, "Cud w nauczaniu
} 
miracles by the Lublin theologian has been presented in separate academic research studies. ${ }^{13}$ Rev. M. Rusecki expands our understanding of miracles in fundamental theology. He moves away from the evidential function of a miracle and shows its motivational function. Rusecki also points out that the biblical miracles also perform other functions, for example, they are revelatory, Christological, royal, salvific, ecclesiological, faith-initiating and benevolent. The multifaceted meaning of miracles as signs from God makes their motivational character visible. In the thaumaturgic literature in the Lublin School of Fundamental Theology, the biblical, personal, sign and historical understanding of miracles prevail.

The issue of miracles was also the topic of doctoral dissertation theses written at the Institute of Fundamental Theology of the Catholic University of Lublin. Under Rev. E. Kopeć's direction, Rev. Tadeusz Czyż wrote his PhD: Personalistyczna koncepcja cudu $w$ apologetyce wspótczesnej [The Personalist Concept of Miracles in Contemporary Apologetics] (defended in 1962). Rev. Andrzej Anderwald defended his PhD thesis in 1996 under Rev. M. Rusecki's supervision: Problem udziału nauk przyrodniczych w procesie rozpoznania cudu. Analiza zagadnienia na przyktadzie literatury niemieckiej $X X$ wieku [The Issue of the Participation of the Natural Sciences in the Process of Recognizing a Miracle. An Analysis of the Issue Based on the Example of XX Century German Literature]. Rev. Casmir Ikechukwu Anozie from Nigeria has prepared a doctorate in English under the direction

\footnotetext{
Marcina Lutra," Z problemów Reformacji 6 (1993): 79-87; Marian RUSECKI, "Maryjny aspekt cudu," Roczniki Teologiczne 40, no 2 (1993): 97-102; Marian RUSECKI, "Bonatywny wymiar cudu," in Z zagadnień dobra i zła wedtug Biblii, ed. Jan Flis (Lublin: RW KUL, 1994), 65-88; Marian RUSECKI, "Czy zmartwychwstanie jest cudem?" in In Te Domine speravi. Księga pamiatkowa poświęcona Księdzu Arcybiskupowi Bolestawowi Pylakowi Metropolicie Lubelskiemu, ed. Czesław S. Bartnik, Hugolin Langkammer, Krzysztof Góźdź (Lublin: RW KUL, 1996), 219-233; Marian RUSECKI, "Jeana Mouroux osobowe ujęcie cudu," in Wszystko czynię dla Ewangelii. Księga Pamiatkowa ku czci O. Prof. Hugolina Langkammera OFM, ed. Gabriel Witaszek, Antoni Paciorek, Andrzej Kiejza (Lublin: RW KUL, 2000), 373-384; Marian RuSECKI, “Teologia cudu," in Cuda w sprawach kanonizacyjnych, ed. Wiesław Bar (Lublin: Wydawnictwo Diecezjalne w Sandomierzu, 2006), 11-94; Marian RuSECKI, "Kryteria historyczności cudów Jezusa," Roczniki Teologiczne 54, no 6 (2007): 317-334.

${ }^{13}$ Andrzej ANDERWALD, "Znakowe ujęcie cudu we współczesnej teologii fundamentalnej. Koncepcja Księdza Mariana Ruseckiego,” in Scio Cui credidi. Księga pamiatkowa ku czci Księdza Profesora Mariana Ruseckiego w 65. rocznice urodzin, red. Ireneusz S. Ledwoń, Krzysztof Kaucha, Zbigniew Krzyszowski, Jacenty Mastej, Andrzej Pietrzak (Lublin: Wydawnictwo KUL, 2007), 99-109; Ryszard ToмCZAK, "Ewolucja interpretacji funkcji cudów Jezusa w teologii XX wieku w ujęciu M. Ruseckiego," in Scio Cui credidi, 111-122.
} 
of Rev. K. Kaucha on The Contemporary Catholic Theology of Miracles (defended in 2018).

\subsection{STAUROLOGICAL AND RESSURECTION THEOLOGY}

The resurrection of Jesus Christ is the heart of Christianity, which is why it is the central field of research for Fundamental Christology. In the Lublin School of Fundamental Theology, we can notice the permanent development of Resurrection theology, which evolved in the direction of a holistic view of the cross and resurrection as one credible event. ${ }^{14}$ The credibility of the cross and resurrection is connected with demonstrating their reality and historicity as well as their revelatory and salvific meaning.

An important place in this process are the New Testament testimonies about the passion, death and resurrection of Jesus Christ. That is why research on the subject of staurology and the resurrection in the Lublin School of Fundamental Theology is thoroughly biblical. It refers to evangelical descriptions of the passion and death, the professions of faith and liturgical hymns of the early Church contained in the apostolic letters and paschal catechisms conveyed in the Acts of the Apostles and evangelical narratives on the topic of the Easter events. Demonstrating the truth of the cross and resurrection demands a holistic discussion of the historicity and theological meaning of the cross, the empty grave and the paschal Christophany. The theological and fundamental perspective also presupposes the apology of the cross and resurrection of Christ in the face of attempts to devaluate and challenge them.

The achievements of the Lublin school of fundamental theology in the field of theological and resurrection theology are impressive. It consists of publications by Rev. E. Kopeć, ${ }^{15}$ Rev. M. Rusecki, ${ }^{16}$ Rev. K. Kaucha, ${ }^{17}$

\footnotetext{
${ }^{14}$ A clear addition to fundamental Christology is the theology of the cross which was evident at the congress of the Section of Fundamental Theologists in Plock-Sikórz, April 16-17, 1998. The theme of the congress was: "Ne evacuata sit crux. Krzyż jako znak i motyw wiarygodności chrześcijaństwa" ["Ne evacuata sit crux. The Cross as a Sign and Motif of the Credibility of Christianity"]. The chairman of the Section of Fundamental Theologians at that time was Rev. Prof. Marian Rusecki. The report on the meeting and the contents of the papers were published in Studia Paradyskie 8 (1998): 179-286.

${ }^{15}$ Edward KopeĆ, “Apologia zmartwychwstania Chrystusa w pierwotnej kerygmie apostolskiej," Roczniki Teologiczno-Kanoniczne 6, no 3 (1959): 57-75; Edward Kopé́, "Problematyka zmartwychwstania Chrystusa w apologetyce współczesnej," Collectanea Theologica 30 (1959): 83-108; Edward Kopeć, “Świadkowie zmartwychwstania Jezusa Chrystusa,” Roczniki Teolo-
} 
Fr. I.S. Ledwon, ${ }^{18}$ Rev. J. Mastej ${ }^{19}$ and Rev. P. Borto. ${ }^{20}$ Noteworthy is the publication by Rev. M. Rusecki, The Lord Resurrected and Is Alive. An Outline of Resurrection Theology (Warsaw: Instytut Wydawniczy PAX, 2006) and Rev. J. Mastej's habilitation dissertation, The Staurologic and Resurrectional Credibility of Christianity (Lublin: Wydawnictwo KUL, 2009).

The topic of the resurrection is also present in the doctorates written under Rev. E. Kopeć: Rev. Kazimierz Skawiński, Pojęcie zmartwychwstania $w$ literaturze XX wieku [The Concept of the Resurrection in $20^{\text {th }}$ Century Literature] (defended in 1979), Rev. Tadeusz Dola, Rozwój interpretacji formuty „zmartwychwstat dnia trzeciego" $w$ teologii $X X$ wieku [The Development of the Interpretation of the Formula "Resurrected on the Third Day" in $20^{\text {th }}$ Century Theology] (defended in 1982). Other doctorates

giczno-Kanoniczne 7, no 1 (1960): 5-43; Edward Kopeć, "Ewangelia św. Pawła jako świadectwo o zmartwychwstaniu Chrystusa," in Ze wspótczesnej problematyki biblijnej, ed. Stanisław Łach (Lublin: TN KUL, 1961), 93-113; Edward KOPEĆ, "Nowe próby interpretacji orędzia paschalnego," Ateneum Kaptańskie 64, no 1-2 (1972): 101-111; Edward KoPEĆ, "Historiozbawczy charakter zmartwychwstania Chrystusa," Roczniki Teologiczno-Kanoniczne 24, no 4 (1977): 107118; Edward KoPEć, "Chrystofanie jako znaki zmartwychwstania Chrystusa," Roczniki Teologiczno-Kanoniczne 25, no 2 (1978): 21-29; Edward KoPEĆ, "Zmartwychwstanie Chrystusa jako realny fakt i wydarzenie zbawcze," in Jezus Chrystus. Historia i tajemnica, 1982.

${ }^{16}$ Marian RusECKI, "Pusty grób i chrystofanie znakami zmartwychwstania. Aspekt metodologiczny," Resovia Sacra 6 (1999): 27-37; Marian RUSECKI, "Formuły wiary i hymny liturgiczne w kerygmacie paschalnym," Roczniki Teologiczne 52, no 9 (2005): 37-50; Marian RUSECKI, "Orędzie św. Piotra o zmartwychwstaniu Jezusa," in In persona Christi. Księga na 80-lecie Księdza Profesora Czestawa S. Bartnika, vol. 1, ed. Krzysztof Góźdź (Lublin: Wydawnictwo KUL, 2009), 349-361; Marian RUSECKI, "Pusty grób znakiem wiarygodności zmartwychwstania," in Zmartwychwstat prawdziwie, ed. Antoni Paciorek, Antoni Tronina, Piotr Łabuda (Tarnów: Biblos, 2010), 339-346.

${ }^{17}$ Jacenty MASTEJ, "Rezurekcyjny charakter posłannictwa Jezusa Chrystusa," Roczniki Teologiczne 54, no 9 (2007): 61-78; Jacenty MASTEJ, "Eklezjogeneza rezurekcyjna," in In persona Christi. Księga na 80-lecie Księdza Profesora Czestawa S. Bartnika, vol. 1, 363-372; Jacenty MASTEJ, "Znaki wiarygodności zmartwychwstania Jezusa Chrystusa," in Pluralizm kulturowy i religijny wspótczesnego świata, ed. Zdzisław Kupisiński, Stanisław Grodź (Lublin: Wydawnictwo KUL, 2010), 199-214; Jacenty MASTEJ, "The Staurological Credibility of the Genesis of the Church," Resovia Sacra 21 (2014), 385-400; Jacenty MASTEJ, "Funkcje zmartwychwstania Jezusa Chrystusa," Roczniki Teologiczne 62, no 9 (2015): 77-100.

${ }^{18}$ Ireneusz S. LEDwoŃ, “Historyczność wydarzeń krzyża,” Studia Paradyskie 8 (1998): 203-226.

${ }^{19}$ Krzysztof KaUcha, "Czy grób naprawdę był pusty? Całun Turyński w teologii fundamentalnej," Roczniki Teologii Fundamentalnej i Religiologii 59, no 4 (2012): 21-49.

${ }^{20}$ Paweł BoRTo, "Znaki Zmartwychwstałego," in Chrześcijańskie świadectwo dzisiaj, ed. Daniel Swend, Paweł Borto (Radom: Wydawnictwo Ave, 2012), 85-112; Paweł BorTo, "Zmartwychwstanie ciała według Katechizmu Kościoła Katolickiego," Kieleckie Studia Teologiczne 12 (2013): 7-26; Paweł BORTO, "Teologicznofundamentalne znaczenie najstarszych nowotestamentalnych formuł wiary w Zmartwychwstanie,” Roczniki Teologiczne 62, no 9 (2015): 55-76. 
include Rev. Mikolaj Węgrzyn, Eklezjogeneza paschalna w świetle polskojęzycznej literatury posoborowej [Paschal Ecclesiogenesis in the Light of Polish-Language Post-Conciliar Literature] (written under the direction of Rev. M. Rusecki and defended in 2007) and Rev. Grzegorz Szubtarski, Paschalna wiarygodność chrześcijaństwa $w$ świetle wybranej posoborowej literatury teologicznej [The Paschal Credibility of Christianity in the Light of Selected Post-Conciliar Theological Literature] (written under the direction of Rev. J. Mastej and defended in 2015), which reveal the connectivity of the staurological and resurrection events preferred by the Lublin School of Fundamental Theology.

\subsection{THE FAITH AND CREDIBILITY OF CHRISTIANITY}

Christological issues occupy a central place in fundamental theology topics related to the faith and the credibility of Christianity. This is due to the goal of fundamental theology, which is to demonstrate the credibility of Christian revelation. On the other hand, if we consider its goal from man's perspective, it would be to demonstrate the rational foundations of the faith. Hence, both the Christian faith and its various conditions, as well as the credibility of Christianity (Revelation), constitute an important element of research at the Lublin School of Fundamental Theology.

The beginnings of a new post-Vatican II personalistic view of the faith and its justification are already visible in the publications by Rev. E. Kopeć ${ }^{21}$ and $\mathrm{PhD}$ theses written under his direction by Rev. Marian Nalepa, Zagadnienie struktury aktu wiary chrześcijańskiej w świetle pogladów Augusta Brunnera [The Problem of the Structure of the Christian Faith in the Light of August Brunner's Views] (defended in 1967), Rev. Stanisław Grzechowiak, Problematyka wiarygodności we wspótczesnej apologetyce [Credibility Issues in Contemporary Apologetics] (defended in 1967), Rev. Edward Łomnicki, Kryteria wiarygodności chrześcijaństwa w ujęciu apologetów starochrześcijańskich [Criteria for the Credibility of Christianity in the Perspective of Old-Christian Apologists] (defended in 1977). The personalist view of the faith, along with the search for new motives for the credibility of Christianity, has been widely developed by Rev. M. Rusecki. ${ }^{22}$

\footnotetext{
${ }^{21}$ Edward Kopeć, "Znaczenie personalistycznej koncepcji wiary dla apologetyki współczesnej," Roczniki Teologiczno-Kanoniczne 11, no 2 (1964): 5-18.

${ }^{22}$ Marian RusecKI, "Miłość jako motyw wiarygodności chrześcijaństwa," in Miłość w postawie ludzkiej, ed. Walerian Słomka (Lublin: TN KUL, 1993), 229-247; Marian RUSECKI, "Problem
} 
A number of new arguments for the credibility of Christianity, which arose in the Lublin School of Fundamental Theology, are presented in the Lexicon of Fundamental Theology ${ }^{23}$ (e.g. agapeological, martyrological, culture-forming, praxeological, benevolent, hopeful, calonistic, and veritative). They are all contained in Revelation and refer to rational reason. Meanwhile, showing the credibility of Christianity in CUL's environment takes place on two parallel levels: the natural one, in which reason and the supernatural play the main role, where cognition is made through faith. The culmination of Rev. M. Rusecki's work on building arguments for the credibility of Christianity is Traktat o wiarygodności chrześcijaństwa. Dlaczego wierzyć Chrystusowi? [Treatise on the Credibility of Christianity. Why Believe Christ?] (Lublin: TN KUL, 2010). Faith and credibility are also often taken up by Fr. I. S. Ledwoń, ${ }^{24}$ Rev. K. Kaucha ${ }^{25}$ and Rev. J. Mastej. ${ }^{26}$

wiarygodności chrześcijaństwa w Katechizmie Kościoła Katolickiego,” Ethos 6, no 4 (1993): 186198; Marian RuSECKI, "Wiara jako odpowiedź człowieka na Boże objawienie," in Katechizm Kościoła Katolickiego. Wprowadzenie, ed. Marian Rusecki, Edward Pudełko (Lublin: RW KUL, 1995), 43-54; Marian RuSECKI, Fenomen chrześcijaństwa. Wktad w kulturę (Lublin: Gaudium, 2001); Marian RUSECKI, "Personalistyczna koncepcja aktu wiary według Jeana Mouroux," in In Christo Redemptore. Ksiegga pamiatkowa ku czci Ks. Profesora Jerzego Misiurka, ed. Jarosław Popławski (Lublin: RW KUL, 2001), 265-279; Marian RUSECKI, "Uzasadnianie wiarygodności chrześcijaństwa," in Ksiądz Profesor Marian Rusecki. Doktor „honoris causa” Papieskiego Wydziału Teologicznego we Wrocławiu (Wrocław: Papieski Wydział Teologiczny, 2012), 61-76.

${ }^{23}$ Ed. M. RusecKi et al., (Lublin-Kraków, 2002).

${ }^{24}$ Ireneusz S. LEDwoŃ, "Znak świętości jako motyw wiarygodności objawienia w ujęciu René Latourelle'a," Roczniki Teologiczne 43, no 2 (1996): 159-170; Ireneusz S. LEDwoń, "Apologia wiary w Katechizmie Kościoła Katolickiego. Perspektywa teologicznofundamentalna," in Catechetica Porta Fidei, ed. Andrzej Kiciński, Piotr Goliszek (Lublin: Natan, 2012), 23-38; Ireneusz S. LEDwoŃ, "Radość jako motyw wiarygodności chrześcijaństwa," in Radość Ewangelii. Biblijne źródta chrześcijańskiej radości, ed. Arnold Zawadzki (Lublin: Wydawnictwo KUL, 2015), 13-23.

${ }^{25}$ Krzysztof KaUCHA, "Arguments for the Credibility of Christianity in John Paul II's Encyclical Fides et ratio," Lateranum. Facoltà di Teologia 70, no 3 (2004): 475-487; Krzysztof KAUCHA, “Argument kaloniczny na wiarygodność chrześcijaństwa," Ethos 19, no 1-2 (2006): 135147; Krzysztof KaUCHA, "Argument kaloniczny," in Marian RUSECKI, Traktat o wiarygodności chrześcijaństwa. Dlaczego wierzyć Chrystusowi? (Lublin: TN KUL, 2010), 211-224; Krzysztof KAUCHA, "Argument werytatywny," in Marian RUSECKI, Traktat o wiarygodności chrześcijaństwa, 172-195; Krzysztof KAUCHA, “Argument metafizyczny w teologii fundamentalnej,” Śląskie Studia Historyczno-Teologiczne 46, no 1 (2013): 52-64; Krzysztof KAUCHA, "Współczesne konteksty chrześcijaństwa i jego wiarygodność," in Wspótczesny kontekst chrześcijaństwa, ed. Przemysław Artemiuk (Płock: Płocki Instytut Wydawniczy, 2016), 234-265.

${ }^{26}$ Jacenty MASTEJ, "Eklezjalny wymiar aktu wiary chrześcijańskiej i jego personalizujące znaczenie," Roczniki Teologiczne 47, no 9 (2000): 105-121; Jacenty MaSTEJ, "Problematyka wiary w deklaracji Dominus Iesus,” in Wokót deklaracji „Dominus Iesus”, ed. Marian Rusecki (Lublin: TN KUL, 2001), 169-186; Jacenty MASTEJ, "Paschalna geneza wiary chrześcijańskiej,” Roczniki Teologiczne 51, no 9 (2004): 97-113; Jacenty MASTEJ, “Apologijny wymiar świadectwa 
Christology related to faith and its credibility was also the topic of doctoral theses at the Lublin School of Fundamental Theology written under the direction of Rev. M. Rusecki: Rev. Jan Salamon, Ewolucja argumentacji chrystologicznej w polskiej literaturze apologetycznej XX wieku [Evolution of Christological Argumentation in $20^{\text {th }}$ Century Polish Apologetic Literature] (defended in 1989), Fr. Ireneusz S. Ledwoń, Pojęcie objawienia chrześcijańskiego i motywy jego wiarygodności wedtug René Latourelle'a [The Concept of Christian Revelation and Motives of its Credibility According to René Latourelle] (defended in 1995), ${ }^{27}$ and Rev. Romuald Kosk, Jezus Chrystus w relacji historiozbawczej w posoborowej literaturze polskiej [Jesus Christ in the Relation of Salvation History in Post-Conciliar Polish Literature] (defended in 1997), Rev. Krzysztof Kaucha, Agapetologiczna wiarygodność chrześcijaństwa wedtug Battisty Mondina [The Agapetologic Credibility of Christianity According to Battista Mondin] (defended in 1998), ${ }^{28}$ Rev. Jacenty Mastej, Personalistyczna koncepcja aktu wiary chrześcijańskiej $w$ świetle polskojęzycznej literatury posoborowej [The Personalistic Concept of the Act of Christian Faith in the Light of Polish-Language Post-Conciliar Literature] (defended in 1999), ${ }^{29}$ Małgorzata Grzenia, Chrystocentryzm dziejów w świetle nauczania Jana Pawła II [Christ Centered History in the Light of John Paul II's Teachings] (defended in 2003). Under the direction of Rev. J. Mastej, Rev. Łukasz Hendzel wrote the dissertation Sperancyjna wiarygodność chrześcijaństwa. Studium teologicznofundamentalne $w$ świetle polskojęzycznej posoborowej literatury

\footnotetext{
wiary chrześcijańskiej," Studia Catholica Podoliae 5 (2006), 219-234; Jacenty MASTEJ, "Sperancyjna wiarygodność chrześcijaństwa w świetle encykliki Benedykta XVI Spe salvi," Roczniki Teologii Fundamentalnej i Religiologii 58, no 3 (2011): 17-35; Jacenty MASTEJ, "Eklezjotwórcza funkcja wiary," Studia Leopoliensia 6 (2013), 181-189; Jacenty MASTEJ, “Świadectwo w argumentacji za wiarygodnością chrześcijaństwa," Verbum Vitae 27(2015): 227-249; Jacenty MASTEJ, "Paksystyczna wiarygodność chrześcijaństwa. Zarys argumentu," in Kościót i dar pokoju, ed. Marek Chojnacki, Józef Morawa, Andrzej A. Napiórkowski (Kraków: Wydawnictwo Salwator, 2016), 201-217; Jacenty MASTEJ, "Inkarnacyjna wiarygodność chrześcijaństwa. Zarys metodologiczny argumentu inkarnacyjnego," Roczniki Teologiczne 64, no 9 (2017): 19-30; Jacenty MASTEJ, "Paschalna wiarygodność chrześcijaństwa i Kościoła według Josepha Ratzingera/Benedicta XVI," in Teologia fundamentalna w twórczości Josepha Ratzingera, ed. Krzysztof Kaucha, Jacenty Mastej (Lublin: Wydawnictwo KUL, 2017), 135-151.

${ }^{27}$ Ireneusz S. LEDwoń, Objawienie chrześcijańskie i jego wiarygodność wedtug René Latourelle'a (Lublin: Polihymnia, 1996).

${ }^{28}$ Krzysztof KaUCHA, Miłość za miłość. Wiarygodność chrześcijaństwa wedtug Battisty Mondina (Lublin: Wydawnictwo KUL, 2000).

${ }^{29}$ Jacenty MASTEJ, Od Objawienia do wiary. Personalistyczna koncepcja aktu wiary chrześcijańskiej (Lublin: RW KUL, 2001).
} 
[The Hopeful Credibility of Christianity. A Theological and Fundamental Study in the Light of Polish-Language Post-Vatican II Literature] (defended in 2013), and under the direction of Fr. I. S. Ledwoń, Ewa Schädler wrote Chrystologia fundamentalna $w$ świetle pism Josepha Ratzingera-Benedykta XVI [Fundamental Christology in the Light of the Writings of Joseph Ratzinger, Benedict XVI] (defended in 2014).

\section{CHRISTOLOGICAL FEATURES OF THE LUBLIN SCHOOL OF FUNDAMENTAL THEOLOGY}

The above presentation of the research carried out at the Lublin School of Fundamental Theology allows us to describe the Lublin School's Christology as biblical (2.1), Christocentrism (2.2.), Personalistic (2.3.), Salvific History (2.4.), Fides et ratio (2.5.), Anthropological (2.6.), Ecclesiological and Ecclesial (2.7.).

\subsection{BIBLICAL CHRISTOLOGY}

A feature of the Christology at the Lublin School of Fundamental Theology is its biblical foundation. For fundamental theology, for example, our findings based on biblical teachings about the genesis of the Gospel are binding. Also, the historicity of miracles and their biblical understanding is the fundamental starting point for theology and the inspiration for developing and deepening the theology of miracles, which takes into account their many functions. The importance of exegesis when understanding staurological and resurrection theology also cannot be overestimated. Fundamental theology uses biblical studies concerning the descriptions of the passion and death of Jesus, as well as the New Testament testimonies of the Resurrection. An important element of Fundamental Christology practiced at the Catholic University of Lublin is its reference to the Old Testament, for example, our new approach to scriptural arguments.

Noteworthy is the multi-faceted and comprehensive cooperation of employees of the Institute of Fundamental Theology with biblical scholars. It is worth emphasizing that the merits of the biblical scholar Rev. Prof. Dr. Hab. J. Kudasiewicz in fundamental theology were greatly appreciated, so 
on September 20, 2005, we granted him the title of an honorary member of the Association of Fundamental Theologians in Poland. ${ }^{30}$

\subsection{CHRISTOCENTRIC CHRYSTOLOGY}

The central figure in fundamental Christology studied at the Catholic University of Lublin is the person of Jesus Christ, which is why we must mention its Christocentrism. ${ }^{31}$ Jesus Christ is the fullness of revelation and salvation. The entire Old Testament prepares for him, and at the same time, it finds its fulfillment and definitive explanation in him. The uniqueness of his person and work determines the absolute character of Christianity as a revealed and salvific religion. The whole argument for the credibility of Christianity finds its center and source of coherence in the person of Jesus Christ.

\subsection{PERSONALISTIC CHRISTOLOGY}

Our Christology at the Lublin School is personalistic. ${ }^{32}$ We consider every person to be a superior reality to the reality that surrounds us, and this is the fundamental hermeneutic principle of philosophical and theological personalism. Only God is entitled to full and proper personal existence. We can speak about the personal existence of a human being in analogy to the Divine Persons. The personalistic nature of fundamental theology is visible

\footnotetext{
${ }^{30}$ The broader contribution by Rev. Prof. Józef Kudasiewicz in developing the Fundamental Theology reflection was presented by Marian Rusecki, "Teologicznofundamentalna myśl Księdza Józefa Kudasiewicza," in: W postudze Stowa Pańskiego. Księga pamiątkowa poświęcona Ks. prof. dr. hab. Józefowi Kudasiewiczowi z okazji 70-lecia urodzin, ed. Stanisław Bielecki, Hubert Ordon, Henryk Witczyk (Kielce: Wydawnictwo Jedność 1997), 23-32.

${ }^{31}$ Edward Kopeć, "Chrystologiczna koncentracja w teologii," Roczniki Teologiczno-Kanoniczne 22, no 2 (1975): 59-71; Edward KoPEĆ, "Znaczenie chrystologicznej koncentracji w teologii współczesnej," in Chrystocentryzm w teologii, ed. Edward Kopeć (Lublin: RW KUL, 1977), 7-16; Marian RUSECKI, "Chrystyczny wymiar zbawczej ekonomii Boga i jej wiarygodność," Roczniki Teologii Fundamentalnej i Religiologii 58, no 3 (2011): 5-16; Ireneusz S. Ledwoń, U źródet chrystocentryzmu w teologii. Święty Franciszek z Asyżu (Kraków: Ośrodek Studiów Franciszkańskich, 2004).

${ }^{32}$ Marian RUSECKI, "Elementy personalistycznej teologii fundamentalnej w ujęciu Edwarda Kopcia," Roczniki Teologiczno-Kanoniczne 32, no 2 (1985): 23-37; Marian RUSECKI, "Zagadnienie personalizmu w pracach badawczych Wydziału Teologii KUL (1968-1993)," Roczniki Teologiczne 43, no 4 (1996): 249-263.
} 
not only in the strictly Christological themes but also in the discussion on God's revelation and faith, ${ }^{33}$ ecclesiological issues ${ }^{34}$ and the methodology of fundamental theology. ${ }^{35}$

\subsection{SALVATION HISTORY CHRISTOLOGY}

The examination and demonstration of the credibility of the Person and mission of Jesus Christ are carried out with the use of the salvation history hermeneutic key. ${ }^{36}$ The historicity of Jesus of Nazareth is the starting point for presenting the essence and value of his saving work. The salvation history hermeneutic key allows the subsequent salvific events to be explained in the perspective of the entire history of salvation, whose definitive fulfillment and interpretor is Jesus Christ. Recognizing the internal logic and salvific meaning given by God to these events is an important premise for demonstrating the credibility of Revelation and Christianity.

\subsection{FIDES ET RATIO CHRISTOLOGY}

The Lublin School of Fundamental Theology deals with Christological research, taking into account both faith and reason. The indications by John Paul II contained in his encyclical Fides et ratio have always accompanied theologians in our academic research community. A perfect example is the arguments mentioned above for the credibility of Christianity, which take into account rational reasons and the level of faith. ${ }^{37}$

\footnotetext{
${ }^{33}$ Krzysztof Guzowski, "Personalizm Objawienia i wiary w ujęciu Ks. prof. Mariana Ruseckiego," in Scio Cui credidi, 75-81.

${ }^{34}$ Marian RUSECKI, "Wiarygodność Kościoła w Polsce jako rzeczywistości personalistycznej i dynamicznej," Studia Warmińskie 30 (1993): 377-390.

${ }^{35}$ Czesław S. BARTNIK, "Metoda znakowo-personalistyczna w ujęciu Profesora Mariana Ruseckiego," in Scio Cui credidi, 69-73; Tadeusz DolA, "Personalistyczna koncepcja teologii fundamentalnej Ks. Mariana Ruseckiego," in Scio Cui credidi, 59-67; Tadeusz Dola, "Personalistyczna koncepcja teologii fundamentalnej Ks. Mariana Ruseckiego," in Personalizm polski, ed. Marian Rusecki (Lublin: Wydawnictwo KUL, 2008), 415-427.

${ }^{36}$ Edward Kopeć, "Chrystologia w świetle historii zbawienia," Ruch Biblijny i Liturgiczny 6 (1953): 74-85.

${ }^{37}$ Marian RUSECKI, "Rozum i wiara z perspektywy teologii fundamentalnej w świetle encykliki Fides et ratio," Analecta Cracoviensia 34 (2002): 241-261; Marian RUSECKI, "Wiara i rozum
} 


\subsection{ANTHROPOLOGICAL CHRISTOLOGY}

Another feature of Lublin's Fundamental Christology is its anthropological foundation. This is emphasized, among others, in the research methods used. When applying subjective methods (e.g. psychological, existential, personalistic), the starting point is man in his specific existence. The end point is to show that Jesus Christ is the personal and definitive answer to man's existential questions. Although subject methods have a different starting point, they aim to show that in the credible reality of Revelation, which occurred in Christ, the God-man, all people can find meaning in their lives, illnesses, sufferings and even death. ${ }^{38}$

Thus, the Lublin center develops and deepens the truth that in Christ, the truth about him is revealed to man, therefore man cannot understand himself without Christ. This clear anthropological feature includes many arguments in the Lublin School of Fundamental Theology, which are contained in the Lexicon of Fundamental Theology or in the Treatise on the Credibility of Christianity by Rev. M. Rusecki, e.g. agapeological, benevolent, praxeological, and hopeful.

\subsection{ECCLESIOLOGICAL AND ECCLESIAL CHRISTOLOGY}

Finally, it is worth noting that the Fundamental Christology at the Lublin center is ecclesiological and ecclesial. This relationship and mutual penetration of the Christological and ecclesiological treatises is visible, and its link is Christ. Traditional fundamental theology essentially consists of two treatises: the Christological and ecclesiological. ${ }^{39} \mathrm{M}$. Rusecki postulates the implicit joint understanding of Jesus Christ and the Church. This is not only about presenting the demonstratio christiana et catholica in uniform con-

\footnotetext{
w świetle encykliki Fides et ratio," in Nauka-wiara. Rola filozofii, ed. Marek Słomka (Lublin: Wydawnictwo KUL, 2009), 109-128.

${ }^{38}$ Marian RUSECKI, "Antropologia paschalna (homo paschalis)," in Instaurare omnia in Christo. O zbawieniu, teologii, dialogu i nadziei. Profesorowi Wacławowi Hryniewiczowi OMI w 70. rocznice urodzin, ed. Przemysław Kantyka (Lublin: Wydawnictwo KUL, 2006), 289-298; Krzysztof KAUCHA, "Sensotwórczy argument w świetle nauczania Jana Pawła II," in Między sensem a bezsensem ludzkiej egzystencji. Teologiczna odpowiedź na fundamentalne pytania wspótczesnego cztowieka, ed. Damian Bryl, Bogusław Kochaniewicz, Janusz Nawrot, Elżbieta Kotkowska (Poznań: Wydział Teologiczny UAM, 2012), 447-460.

${ }^{39}$ Often, the treatise on religion is also included in Fundamental Theology.
} 
ceptual categories, but also permanently showing the unity of Christ and his Church. ${ }^{40}$ The Christology of the Lublin School of Fundamental Theology is also ecclesiastical, because academic research is carried out in unity with the Magisterium of the Church.

The goal of this article was to show the achievements of the Lublin school of fundamental theology in the field of Christology. The first part presents a short outline of Christological research while at the same time expressing the most important research publications of the Lublin center in the field of Christology. The second part presents the essential features of Lublin's Fundamental Christology. Keeping in mind the above-mentioned academic achievements of the Lublin School of Fundamental Theology, its contribution to the development of Fundamental Christology in Poland after the Second Vatican Council should be appreciated.

\section{BIBLIOGRAPHY}

ANDERWALD, Andrzej. "Znakowe ujęcie cudu we współczesnej teologii fundamentalnej. Koncepcja Księdza Mariana Ruseckiego" ["Miracles as Signs in Contemporary Fundamental Theology. The Concept of Rev. Marian Rusecki”]. In Scio Cui credidi. Ksiega pamiatkowa ku czci Księdza Profesora Mariana Ruseckiego w 65. rocznicę urodzin [Scio Cui credidi. A Memorial Book in Honor of Professor Marian Rusecki on his $65^{\text {th }}$ Birthday], edited by Ireneusz S. Ledwoń, Krzysztof Kaucha, Zbigniew Krzyszowski, Jacenty Mastej, Andrzej Pietrzak, 99109. Lublin: Wydawnictwo KUL, 2007.

BARTniK, Czesław S. "Metoda znakowo-personalistyczna w ujęciu Profesora Mariana Ruseckiego" ["The Sign and Personalistic Method according to Professor Marian Rusecki"]. In Scio Cui credidi. Księga pamiątkowa ku czci Księdza Profesora Mariana Ruseckiego w 65. rocznice urodzin [Scio Cui credidi. A Memorial Book in Honor of Professor Marian Rusecki on his $65^{\text {th }}$ Birthday], edited by Ireneusz S. Ledwoń, Krzysztof Kaucha, Zbigniew Krzyszowski, Jacenty Mastej, Andrzej Pietrzak, 69-73. Lublin: Wydawnictwo KUL, 2007.

BORTO, Paweł. "Teologiczno-fundamentalne znaczenie najstarszych nowotestamentalnych formuł wiary w Zmartwychwstanie" ["The Theological and Fundamental Significance of the Oldest

\footnotetext{
${ }^{40}$ RUSECKI, Wiarygodność chrześcijaństwa, vol. 1, 218-222; Marian RUSECKI, "Łączność chrystologii z eklezjologią w teologii fundamentalnej w aspekcie metodologicznym," in Świadek Chrystusowych cierpień. Księga Pamiątkowa dedykowana Ks. profesorowi Adamowi Kubisiowi, bytemu rektorowi PAT, ed. Józef Morawa (Kraków: Wydawnictwo PAT, 2004), 669-688; Marian RUSECKI, Jacenty MASTEJ, "Metodologia chrystologii fundamentalnej. Demonstratio christiana," Studia Nauk Teologicznych PAN 2 (2007): 109-114.
} 
New Testament Formulas of Faith in the Resurrection"]. Roczniki Teologiczne 62, no 9 (2015): 55-76.

Borto, Paweł. "Zmartwychwstanie ciała według Katechizmu Kościoła Katolickiego” ["Resurrection of the Body according to the Catechism of the Catholic Church"]. Kieleckie Studia Teologiczne 12 (2013): 7-26.

Borto, Paweł. "Znaki Zmartwychwstałego" ["Signs of the Risen Lord”]. In Chrześcijańskie świadectwo dzisiaj [Christian Testimony Today], edited by Daniel Swend, Paweł Borto, 85112. Radom: Wydawnictwo Ave, 2012.

DolA, Tadeusz. "Personalistyczna koncepcja teologii fundamentalnej Ks. Mariana Ruseckiego" ["The Personalistic Concept of Fundamental Theology by Rev. Marian Rusecki”]. In Scio Cui credidi. Księga pamiątkowa ku czci Księdza Profesora Mariana Ruseckiego w 65. rocznice urodzin [Scio Cui credidi. A Memorial Book in Honor of Professor Marian Rusecki on his $65^{\text {th }}$ Birthday], edited by Ireneusz S. Ledwoń, Krzysztof Kaucha, Zbigniew Krzyszowski, Jacenty Mastej, Andrzej Pietrzak, 59-67. Lublin: Wydawnictwo KUL, 2007.

DolA, Tadeusz. "Personalistyczna koncepcja teologii fundamentalnej Ks. Mariana Ruseckiego" The Personalistic Concept of Fundamental Theology by Rev. Marian Rusecki"]. In Personalizm polski [Polish Personalism], edited by Marian Rusecki, 415-427. Lublin: Wydawnictwo KUL, 2008.

Guzowski, Krzysztof. "Personalizm Objawienia i wiary w ujęciu Ks. Prof. Mariana Ruseckiego" ["The Personalism of Revelation and Faith according to Rev. Prof. Marian Rusecki"]. In Scio Cui credidi. Księga pamiątkowa ku czci Księdza Profesora Mariana Ruseckiego w 65. rocznice urodzin [Scio Cui credidi. A Memorial Book in Honor of Professor Marian Rusecki on his $65^{\text {th }}$ Birthday], edited by Ireneusz S. Ledwoń, Krzysztof Kaucha, Zbigniew Krzyszowski, Jacenty Mastej, Andrzej Pietrzak, 75-81. Lublin: Wydawnictwo KUL, 2007.

KaUcha, Krzysztof. "Argument kaloniczny" ["The Calonical Argument”]. In Marian Rusecki. Traktat o wiarygodności chrześcijaństwa. Dlaczego wierzyć Chrystusowi? [Marian Rusecki. Treatise on the Credibility of Christianity. Why Believe Christ?], 211-224. Lublin: TN KUL, 2010.

KaUCHA, Krzysztof. "Argument metafizyczny w teologii fundamentalnej” ["The Metaphysical Argument in Fundamental Theology”]. Śląskie Studia Historyczno-Teologiczne 46, no 1 (2013): 52-64.

KaUCHA, Krzysztof. "Argument werytatywny" ["The Credibility Argument”]. In Marian RUSECKI. Traktat o wiarygodności chrześcijaństwa. Dlaczego wierzyć Chrystusowi? [Marian Rusecki. Treatise on the Credibility of Christianity. Why Believe Christ?], 172-195. Lublin: TN KUL, 2010.

KAUCHA, Krzysztof. “Argument kaloniczny na wiarygodność chrześcijaństwa” ["The Calonical Argument on the Reliability of Christianity"]. Ethos 19, no 1-2 (2006): 135-147.

KAUCHA, Krzysztof. "Arguments for the credibility of Christianity in John Paul II's Encyclical Fides et ratio.” Lateranum. Facoltà di Teologia 70, no 3 (2004): 475-487.

Kaucha, Krzysztof. "Czy grób naprawdę był pusty? Całun Turyński w teologii fundamentalnej” ["Was the Grave Really Empty? The Shroud of Turin in Fundamental Theology"]. Roczniki Teologii Fundamentalnej i Religiologii 59, no 4 (2012): 21-49.

KaUcha, Krzysztof. Miłość za mitość. Wiarygodność chrześcijaństwa według Battisty Mondina [Love for Love. The Credibility of Christianity According to Battista Mondin]. Lublin: Wydawnictwo KUL, 2000. 
KAUCHA, Krzysztof. "Sensotwórczy argument w świetle nauczania Jana Pawła II" ["A Meaningful Argument in the Light of the Teachings of John Paul II"]. In Między sensem a bezsensem ludzkiej egzystencji. Teologiczna odpowiedź na fundamentalne pytania wspótczesnego człowieka [Between the Meaning and the Nonsense of Human Existence. Theological Answers to the Fundamental Questions of Modern Man], edited by Damian Bryl, Bogusław Kochaniewicz, Janusz Nawrot, Elżbieta Kotkowska, 447-460. Poznań: Wydział Teologiczny UAM, 2012.

KAUCHA, Krzysztof. "Wiarygodność i wiara w ujęciu lubelskiej szkoły teologii fundamentalnej” ["Credibility and Faith in the Lublin School of Fundamental Theology"]. In Wiara-wiarygodność [Faith—Credibility], edited by Damian Wąsek, 49-85. Kraków: Wydawnictwo Naukowe UPJPII w Krakowie, 2014.

KAUCHA, Krzysztof. "Współczesne konteksty chrześcijaństwa i jego wiarygodność” ["Contemporary Contexts of Christianity and its Credibility"]. In: Współczesny kontekst chrześcijaństwa [The Contemporary Context of Christianity], edited by Przemysław Artemiuk, 234-265. Płock: Płocki Instytut Wydawniczy, 2016.

Kopeć, Edward. "Apologia zmartwychwstania Chrystusa w pierwotnej kerygmie apostolskiej” ["Apology of the Resurrection of Christ in the Original Apostolic Kerygma"]. Roczniki Teologiczno-Kanoniczne 6, no 3 (1959): 57-75.

Kopeć, Edward. "Chrystofanie jako znaki zmartwychwstania Chrystusa” [“Christophanies as Signs of the Resurrection of Christ”]. Roczniki Teologiczno-Kanoniczne 25, no 2 (1978): 21-29.

Kopeć, Edward. "Chrystologia w świetle historii zbawienia" ["Christology in the Light of Salvation History"]. Ruch Biblijny i Liturgiczny 6 (1953): 74-85.

Kopeć, Edward. "Chrystologiczna koncentracja w teologii" ["Christological Concentration in Theology”]. Roczniki Teologiczno-Kanoniczne 22, no 2 (1975): 59-71.

Kopeć, Edward. "Ewangelia św. Pawła jako świadectwo o zmartwychwstaniu Chrystusa" ["The Gospel of St. Paul as a Testimony of the Resurrection of Christ”]. In Ze wspótczesnej problematyki biblijnej [From Contemporary Biblical Issues], edited by Stanisław Łach, 93-113. Lublin: TN KUL, 1961.

KoPEĆ, Edward. "Historiozbawczy charakter zmartwychwstania Chrystusa" ["The Historical Character of the Resurrection of Christ"]. Roczniki Teologiczno-Kanoniczne 24, no 4 (1977): 107-118.

Kopeć, Edward. "Historyczne istnienie Jezusa Chrystusa" ["The Historical Existence of Jesus Christ"]. In Jezus Chrystus. Historia i Tajemnica [Jesus Christ. History and Mystery], edited by Wincenty Granat, Edward Kopeć, 73-99. Lublin: TN KUL, 1982.

Kopeć, Edward. "Nowe próby interpretacji orędzia paschalnego" ["New Attempts to Interpret the Paschal Message"]. Ateneum Kaptańskie 64, no 1-2 (1972): 101-111.

Kopeć, Edward. "Problematyka rozpoznania cudu" ["Problems in Recognizing Miracles"]. Roczniki Teologiczno-Kanoniczne 13, no 2 (1966): 5-22.

KoPeĆ, Edward. "Problematyka zmartwychwstania Chrystusa w apologetyce współczesnej" ["Issues on Christ's Resurrection in Contemporary Apologetics"]. Collectanea Theologica 30 (1959): 83-108.

KoPEĆ, Edward. Teologia fundamentalna [Fundamental Theology]. Lublin: RW KUL, 19763.

Kopeć, Edward. "Über den motivationswert des Wunders." Collectanea Theologica 46 (1976), f. spec.: 45-57.

Kopeć, Edward. "Walor motywacyjny cudów” [“The Motivational Value of Miracles”]. Roczniki Teologiczno-Kanoniczne 19, no 2 (1972): 99-110. 
Kopeć, Edward. "Zmartwychwstanie Chrystusa jako realny fakt i wydarzenie zbawcze" ["The Resurrection of Christ as a Real Fact and a Salvific Event"]. In Jezus Chrystus. Historia i tajemnica [Jesus Christ. History and Mystery], edited by Wincenty Granat, Edward Kopeć, 246-277. Lublin: TN KUL, 1982.

KOPEĆ, Edward. "Znaczenie chrystologicznej koncentracji w teologii współczesnej” ["The Importance of the Christological Focus in Contemporary Theology"]. In Chrystocentryzm w teologii [Christocentrism in Theology], edited by Edward Kopeć, 7-16. Lublin: RW KUL, 1977.

KoPEĆ, Edward. "Znaczenie personalistycznej koncepcji wiary dla apologetyki współczesnej” ["The Importance of the Personalistic Concept of Faith for Contemporary Apologetics"]. Roczniki Teologiczno-Kanoniczne 11, no 2 (1964): 5-18.

Kopeć, Edward. "Problematyka cudu w apologetyce współczesnej" ["The Problem of Miracles in Contemporary Apologetics"]. In Pod tchnieniem Ducha Świętego [The Breath of the Holy Spirit], edited by Marian Finke, 267-282. Poznań-Warszawa-Lublin: Księgarnia Św. Wojciecha, 1964

Kopeć, Edward. "Świadkowie zmartwychwstania Jezusa Chrystusa" [Witnesses of the Resurrection of Jesus Christ]. Roczniki Teologiczno-Kanoniczne 7, no 1 (1960): 5-43.

Ledwoń, Ireneusz S. "Apologia wiary w Katechizmie Kościoła Katolickiego. Perspektywa teologicznofundamentalna" ["Faith Apologetics in the Catechism of the Catholic Church. A Theoretical and Fundamental Perspective"]. In Catechetica Porta Fidei, edited by Andrzej Kiciński, Piotr Goliszek, 23-38. Lublin: Natan, 2012.

LEDwoń, Ireneusz S. Historyczność Jezusa Chrystusa. Skrypt dla doktorantów [The Historicity of Jesus Christ. Script for PhD Students]. Lublin: Wydawnictwo KUL, 2010.

LEDWOŃ, Ireneusz S. Objawienie chrześcijańskie i jego wiarygodność wedtug René Latourelle'a [Christian Revelation and its Credibility according to René Latourelle]. Lublin: Polihymnia, 1996.

LEDwoń, Ireneusz S. "Historyczność wydarzeń krzyża" ["Historicity of the Events of the Cross"]. Studia Paradyskie 8 (1998): 203-226.

LEDwoń, Ireneusz S. "Radość jako motyw wiarygodności chrześcijaństwa" ["Joy as a Motif of Christianity Credibility”]. In Radość Ewangelii. Biblijne źródła chrześcijańskiej radości [The Joy of the Gospel. Biblical Sources of Christian Joy], edited by Arnold Zawadzki, 13-23. Lublin: Wydawnictwo KUL, 2015.

LeDwoń, Ireneusz S. U źródet chrystocentryzmu w teologii. Święty Franciszek z Asyżu [At the Source of Christocentrism in Theology. Saint Francis of Assisi]. Kraków: Ośrodek Studiów Franciszkańskich 2004.

LEDwoŃ, Ireneusz S. "Znak świętości jako motyw wiarygodności objawienia w ujęciu René Latourelle' a" ["The Sign of Holiness as the Motive for the Credibility of Revelation according to René Latourelle"]. Roczniki Teologiczne 43, no 2 (1996): 159-170.

MASTEJ, Jacenty. “Apologijny wymiar świadectwa wiary chrześcijańskiej” [“The Apologetic Dimension of the Testimony of the Christian Faith"]. Studia Catholica Podoliae 5 (2006): 219-234.

MAsteJ, Jacenty. "Czy Jezus wiedział, że jest Mesjaszem? Mesjańska świadomość Jezusa z Nazaretu" ["Did Jesus know that he Was the Messiah? The Messianic Consciousness of Jesus of Nazareth"]. Lumen Bibliae 4 (2014): 117-134.

MASTEJ, Jacenty. "Eklezjalny wymiar aktu wiary chrześcijańskiej i jego personalizujące znaczenie" ["The Ecclesial Dimension of the Act of the Christian Faith and its Personalizing Significance"]. Roczniki Teologiczne 47, no 9 (2000): 105-121. 
MASTEJ, Jacenty. "Eklezjogeneza rezurekcyjna" ["The Ecclesio-genesis Resurrection"]. In In persona Christi. Księga na 80-lecie Księdza Profesora Czesława S. Bartnika [In Persona Christi. Memoral Book for Father Czesław S. Bartnik on his $80^{\text {th }}$ Birthday], edited by Krzysztof Góźdź, vol. 1, 363-372. Lublin: Wydawnictwo KUL, 2009.

MASTEJ, Jacenty. "Eklezjotwórcza funkcja wiary" [“The Ecclesiological Function of the Faith"]. Studia Leopoliensia 6 (2013): 181-189.

MASTEJ, Jacenty. "Funkcje zmartwychwstania Jezusa Chrystusa" ["The Functions of the Resurrection of Jesus Christ”]. Roczniki Teologiczne 62, no 9 (2015): 77-100.

MASTEJ, Jacenty. “Inkarnacyjna wiarygodność chrześcijaństwa. Zarys metodologiczny argumentu inkarnacyjnego" ["The Incarnational Credibility of Christianity. The Methodological Outline of the Incarnation Argument"]. Roczniki Teologiczne 64, no 9 (2017): 19-30.

MASTEJ, Jacenty. Od Objawienia do wiary. Personalistyczna koncepcja aktu wiary chrześcijańskiej [From Revelation to Faith. The Personalistic Concept of the Act of Christian Faith]. Lublin: RW KUL, 2001.

MASTEJ, Jacenty. "Paksystyczna wiarygodność chrześcijaństwa. Zarys argumentu" ["The Pacifist Credibility of Christianity. An Outline of the Argument"]. In Kościót i dar pokoju [The Church and the Gift of Peace], edited by Marek Chojnacki, Józef Morawa, Andrzej A. Napiórkowski, 201-217. Kraków: Wydawnictwo Salwator, 2016.

MASTEJ, Jacenty. "Paschalna geneza wiary chrześcijańskiej" ["The Paschal Origin of the Christian Faith”]. Roczniki Teologiczne 51, no 9 (2004): 97-113.

MASTEJ, Jacenty. "Paschalna wiarygodność chrześcijaństwa i Kościoła według Josepha Ratzingera / Benedicta XVI" ["The Paschal Credibility of Christianity and the Church according to Joseph Ratzinger / Benedict XVI"]. In Teologia fundamentalna w twórczości Josepha Ratzingera [Fundamental Theology in the Works of Joseph Ratzinger], edited by Krzysztof Kaucha, Jacenty Mastej, 135-151. Lublin: Wydawnictwo KUL, 2017.

MAsteJ, Jacenty. "Problematyka wiary w deklaracji Dominus Iesus" ["Faith Issues in the Dominus Iesus Declaration”]. In Wokót deklaracji „Dominus Iesus” [Concerning the Declaration "Dominus Iesus"], edited by Marian Rusecki, 169-186. Lublin: TN KUL, 2001.

MASTEJ, Jacenty. "Sperancyjna wiarygodność chrześcijaństwa w świetle encykliki Benedykta XVI Spe salvi" ["Hope as Credibility for Christianity in the Light of the of Benedict XVI's Encyclical Spe salvi”]. Roczniki Teologii Fundamentalnej i Religiologii 58, no 3 (2011): 17-35.

MASTEJ, Jacenty. Staurologiczno-rezurekcyjna wiarygodność chrześcijaństwa [The StaurologicalResurrection Credibility of Christianity]. Lublin: Wydawnictwo KUL, 2009.

MASTEJ, Jacenty. "Świadectwo w argumentacji za wiarygodnością chrześcijaństwa" ["Testimony in Arguments for the Credibility of Christianity"]. Verbum Vitae 27 (2015): 227-249.

MASTEJ, Jacenty. "The Staurological Credibility of the Genesis of the Church." Resovia Sacra 21 (2014): 385-400.

MASTEJ, Jacenty. "Znaki wiarygodności zmartwychwstania Jezusa Chrystusa” ["Signs of the Credibility of the Resurrection of Jesus Christ"]. In Pluralizm kulturowy i religijny wspótczesnego świata [Cultural and Religious Pluralism in the Modern World], edited by Zdzisław Kupisiński, Stanisław Grodź, 199-214. Lublin: Wydawnictwo KUL, 2010.

MASTEJ, Jacenty. "Rezurekcyjny charakter posłannictwa Jezusa Chrystusa" ["The Resurrection Nature of the Mission of Jesus Christ"]. Roczniki Teologiczne 54, no 9 (2007): 61-78.

NAGY, Stanisław. "Sekcja Teologii Fundamentalnej” [“The Fundamental Theology Section”]. In Księga pamiatkowa w 75-lecie Katolickiego Uniwersytetu Lubelskiego. Wkład w kulturę polska 
$w$ latach 1968-1993 [Memorial Book on the $75^{\text {th }}$ Anniversary of the Catholic University of Lublin. Its Contribution to Polish Culture in 1968-1993], edited by Marian Rusecki, 188197. Lublin: Wydawnictwo KUL, 1994.

RUSECKI, Marian, Jacenty MASTEJ. "Metodologia chrystologii fundamentalnej. Demonstratio christiana" ["Methodology of Fundamental Christology. Demonstratio Christiana"]. Studia Nauk Teologicznych PAN 2 (2007): 97-115.

Rusecki, Marian, Jarosław PopŁawski, Jacenty Mastej. "Historyczność Jezusa Chrystusa.” In Leksykon Teologii Fundamentalnej ["The Historicity of Jesus Christ." In: Lexicon of Fundamental Theology] edited by Marian Rusecki, Krzysztof Kaucha, Ireneusz S. Ledwoń, Jacenty Mastej, 504-521. Lublin-Kraków: Wydawnictwo M 2002.

RUSECKI, Marian. "Antropologia paschalna (homo paschalis)." In Instaurare omnia in Christo. O zbawieniu, teologii, dialogu i nadziei. Profesorowi Wacławowi Hryniewiczowi OMI w 70. rocznice urodzin ["Paschal Anthropology (homo paschalis)." In: Instaurare Omnia in Christo. About Salvation, Theology, Dialogue and Hope. On Professor Wacław Hryniewicz OMI's $70^{\text {th }}$ Birthday], edited by Przemysław Kantyka, 289-298. Lublin: Wydawnictwo KUL, 2006.

RUSECKI, Marian. "Bonatywny wymiar cudu." In Z zagadnień dobra i zła wedtug Biblii ["The Benevolent Dimension of Miracles." In: From the Problems of Good and Evil according to the Bible], edited by Jan Flis, 65-88. Lublin: RW KUL, 1994.

RUSECKI, Marian. "Chrystyczny wymiar zbawczej ekonomii Boga i jej wiarygodność" ["Christ's Dimension of God's Salvation Economy and its Credibility”]. Roczniki Teologii Fundamentalnej i Religiologii 58, no 3 (2011): 5-16.

Rusecki, Marian. "Cud a słowo" ["Miracles and the Word"]. Roczniki Teologiczno-Kanoniczne 30, no 6 (1983): 229-238.

RUSECKI, Marian. "Cud jako znak i symbol” ["Miracles as Signs and Symbols"]. Roczniki Teologiczno-Kanoniczne 28, no 2 (1981): 79-95.

RUSECKI, Marian. "Cud w apologetyce F.D.E. Schleiermachera" ["Miracles in the Apologetics of F.D.E Schleiermacher”]. Roczniki Teologiczno-Kanoniczne 35, no 2 (1988): 83-94.

RuSECKI, Marian. "Cud w apologetycznej myśli Błażeja Pascala” ["Miracles in the Apologetic Thoughts of Blaise Paschal"]. Roczniki Teologiczno-Kanoniczne 37, no 2 (1990): 5-20.

RUSECKI, Marian. Cud w chrześcijaństwie [Miracles in Christianity]. Lublin: TN KUL, 1996.

RuSECKI, Marian. Cud w myśli chrześcijańskiej [Miracles in Christian Thought]. Lublin: TN KUL, 1991.

RUSECKI, Marian. "Cud w nauczaniu Marcina Lutra" [Miracles in the Teachings of Martin Luther]. Z problemów Reformacji 6 (1993): 79-87.

RuSECKI, Marian. "Czy zmartwychwstanie jest cudem?” In In Te Domine speravi. Księga pamiątkowa poświęcona Księdzu Arcybiskupowi Bolesławowi Pylakowi Metropolicie Lubelskie$m и$ [“Is the Resurrection a Miracle?" In: In Te Domine speravi. A Memorial Book Dedicated to Archbishop Bolesław Pylak, Metropolitan of Lublin], edited by Czesław S. Bartnik, Hugolin Langkammer, Krzysztof Góźdź, 219-233. Lublin: RW KUL, 1996.

RUSECKI, Marian. "Elementy personalistycznej teologii fundamentalnej w ujęciu Edwarda Kopcia" ["Elements of Personalistic Fundamental Theology according to Edward Kopeć"]. Roczniki Teologiczno-Kanoniczne 32, no 2 (1985): 23-37.

RUSECKI, Marian. "Ewolucja funkcji motywacyjnej cudu w genezie aktu wiary" ["The Evolution of the Motivational Function of Miracles in the Genesis of the Act of Faith"]. Roczniki Teologiczno-Kanoniczne 33, no 2 (1986): 95-120. 
RuSECKI, Marian. Fenomen chrześcijaństwa. Wktad w kulturę [The Phenomenon of Christianity. Its Contribution to Culture]. Lublin: Gaudium, 2001.

RUSECKI, Marian. "Formuły wiary i hymny liturgiczne w kerygmacie paschalnym" ["Faith Formulas and Liturgical Hymns in the Paschal Kerygma"]. Roczniki Teologiczne 52, no 9 (2005): 37-50.

RUSECKI, Marian. "Funkcja argumentacyjna cudu w pierwszych trzech wiekach Kościoła" ["The Argumentative Function of Miracles in the First Three Centuries of the Church"]. Roczniki Teologiczno-Kanoniczne 26, no 2 (1979): 29-40.

RUSECKI, Marian. "Funkcje cudu jako znaku" ["The Function of Miracles as Signs"]. Roczniki Teologiczno-Kanoniczne 27, no 2 (1980): 51-70.

RuSECKI, Marian. Funkcje cudu. Sandomierz-Lublin: Wydawnictwo Diecezjalne, 1997.

RUSECKI, Marian. Gottes Wirken in der Welt. Dimensionen und Funktionen des biblischen Wunderbegriffs. Frankfurt am Main: Peter Lang Europäischer Verlag der Wissenschaften, 2001.

RUSECKI, Marian. "Historyczne istnienie Jezusa z Nazaretu. Źródła poznania.” In Być chrześcijaninem dziś. Teologia dla szkót średnich ["The Historical Existence of Jesus of Nazareth. Sources of Cognition.” In: Being a Christian Today. Theology for Secondary Schools], edited by Marian Rusecki, 138-146. Lublin: RW KUL, 1992.

RUSECKI, Marian. "J.H. Newmana religijne rozumienie cudu.” In Historia i Logos. Ksiega pamiątkowa ku czci Ks. prof. Czestawa S. Bartnika [“J.H. Newman's Religious Understanding of Miracles." In: History and Logos. A Memorial Book in Honor of Rev. Prof. Czesław S. Bartnik], edited by Kazimierz Macheta, Krzysztof Góźdź, Mirosław Kowalczyk, 116-129. Lublin: RW KUL, 1991.

RUSECKI, Marian. "Jeana Mouroux osobowe ujęcie cudu." In Wszystko czynię dla Ewangelii. Księga Pamiatkowa ku czci O. Prof. Hugolina Langkammera OFM ["Jean Mouroux's Personalistic Concept of Miracles." In: I Do Everything for the Gospel. Memorial Book in Honor of Father Hugolin Langkammer OFM], edited by Gabriel Witaszek, Antoni Paciorek, Andrzej Kiejza, 373-384. Lublin: RW KUL, 2000.

RuSECKI, Marian. "Kryteria historyczności cudów Jezusa" ["Criteria of the Historicity of the Miracles of Jesus"]. Roczniki Teologiczne 54, no 6 (2007): 317-334.

RUSECKI, Marian. "Łączność chrystologii z eklezjologią w teologii fundamentalnej w aspekcie metodologicznym" ["The Connection between Christology with Ecclesiology in Fundamental Theology in the Methodological Aspect”]. In Świadek Chrystusowych cierpień. Ksiegga Pamiątkowa dedykowana Ks. profesorowi Adamowi Kubisiowi, byłemu rektorowi PAT [Witness of Christ's Sufferings. Memorial Book Dedicated to Rev. Professor Adam Kubisi, Former Rector of PAT], edited by Józef Morawa, 669-688. Kraków: Wydawnictwo PAT 2004.

Rusecki, Marian. "Maryjny aspekt cudu" ["The Marian Aspect of Miracles"]. Roczniki Teologiczne 40, no 2 (1993): 97-102.

RUSECKI, Marian. "Miłość jako motyw wiarygodności chrześcijaństwa" ["Love as a Motif of Christianity's Credibility"]. In Miłość w postawie ludzkiej [Love in Human Attitudes], edited by Walerian Słomka, 229-247. Lublin: TN KUL, 1993.

RUSECKI, Marian. "Modele uzasadnień wiarygodności chrześcijaństwa” ["Models for Justifying the Credibility of Christianity"]. In Chrześcijaństwo jutra. Materiały II Międzynarodowego Kongresu Teologii Fundamentalnej. Lublin, 18-21 września 2001 [Christianity Tomorrow. Materials of the II International Congress of Fundamental Theology. Lublin, September 1821, 2001], edited by Marian Rusecki, Krzysztof Kaucha, Zbigniew Krzyszowski, Ireneusz S. Ledwoń, Jacenty Mastej, 355-402. Lublin: TN KUL, 2001. 
RuSECKI, Marian. "O księdzu profesorze Edwardzie Kopciu i jego wkładzie w polską teologię fundamentalną" ["About Father Professor Edward Kopeć and his Contribution to Polish Fundamental Theology"]. In Teologia wobec zjawisk paranormalnych [Theology towards Paranormal Phenomena], edited by Krzysztof Kaucha, Jacenty Mastej, 5-13. Lublin: Wydawnictwo KUL, 2011.

RuSECKI, Marian. “Orędzie św. Piotra o zmartwychwstaniu Jezusa” [“St. Peter's Message about the Resurrection of Jesus”]. In "In persona Christi.” Księga na 80-lecie Księdza Profesora Czestawa S. Bartnika [“In persona Christi.” A Book for Rev. Professor Czesław S. Bartnik on his 80 ${ }^{\text {th }}$ Birthday], vol. 1, edited by Krzysztof Góźdź, 349-361. Lublin: Wydawnictwo KUL, 2009.

RUSECKI, Marian. Pan zmartwychwstat i żyje. Zarys teologii rezurekcyjnej [The Lord Is Resurrected and Alive. Outline of Resurrection Theology]. Warsaw: Instytut Wydawniczy PAX, 2006.

RuSECKI, Marian. "Pedagogiczne funkcje cudu według św. Grzegorza Wielkiego" ["Pedagogical Functions of Miracles according to St. Gregory the Great"]. Roczniki Teologiczno-Kanoniczne 30, no 2 (1983): 33-49.

RUSECKI, Marian. "Personalistyczna koncepcja aktu wiary według Jeana Mouroux" ["The Personalistic Concept of the Act of Faith according to Jean Mouroux"]. In In Christo Redemptore. Księga pamiątkowa ku czci Ks. Profesora Jerzego Misiurka [In Christo Redemptore. A Memorial Book in Honor of Rev. Professor Jerzy Misiurek], edited by Jarosław Popławski, 265279. Lublin: RW KUL, 2001.

Rusecki, Marian. "Pozachrześcijańskie świadectwa o historycznym istnieniu Jezusa" ["Non-Christian Testimonies about the Historical Existence of Jesus"]. In Najważniejsza jest miłość. Księga pamiątkowa ku czci Księdza Profesora Waleriana Słomki [Love Is Most Important. A Memorial Book in Honor of Rev. Professor Walerian Słomka.], edited by Marek Chmielewski, 361-375. Lublin: RW KUL, 1999.

RUSECKI, Marian. Problem cudu w religiach pozachrześcijańskich [The Issue of Miracles in NonChristian Religions]. Lublin: TN KUL, 2001.

RUSECKI, Marian. "Problem dowodzenia z cudu w drugiej szkole augustyńskiej” ["The Issue of Proving Miracles in the Second Augustinian School"]. Roczniki Teologiczno-Kanoniczne 35, no 2 (1988): 65-82.

RUSECKI, Marian. "Problem wiarygodności chrześcijaństwa w Katechizmie Kościoła Katolickiego" ["The Issue of Christianity's Credibility in the Catechism of the Catholic Church"]. Ethos 6, noo 4 (1993): 186-198.

RUSECKI, Marian. "Pusty grób i chrystofanie znakami zmartwychwstania. Aspekt metodologiczny" ["The Empty Tomb and Christophany as Signs of Resurrection. The Methodological Aspect"]. Resovia Sacra 6 (1999): 27-37.

RUSECKI, Marian. "Pusty grób znakiem wiarygodności zmartwychwstania" ["The Empty Tomb as a Sign of the Credibility of the Resurrection"]. In Zmartwychwstat prawdziwie [He has Truly Resurrected], edited by Antoni Paciorek, Antoni Tronina, Piotr Łabuda, 339-346. Tarnów: Biblos, 2010.

RUSECKI, Marian. "Rola motywacyjna cudu według św. Tomasza z Akwinu” ["The Motivational Role of Miracles according to St. Thomas Aquinas”]. Roczniki Teologiczno-Kanoniczne 26, no 3 (1979): 93-106.

RUSECKI, Marian. "Rozum i wiara z perspektywy teologii fundamentalnej w świetle encykliki Fides et ratio" ["Reason and Faith from the Perspective of Fundamental Theology in the Light of the Fides et ratio"]. Analecta Cracoviensia 34 (2002): 241-261. 
RUSECKI, Marian. "Soteryczny wymiar cudu" ["The Soteric Dimension of Miracles"]. Collectanea Theologica 58, no 1 (1988): 71-87.

RUSECKI, Marian. "Świętego Augustyna teologiczne rozumienie cudu i jego funkcji” ["St. Augustine's Theological Understanding of Miracles and their Functions"]. Roczniki Teologiczno-Kanoniczne 31, no 2 (1984): 107-124.

RUSECKI, Marian. "Teofanijny charakter cudu" ["The Theophanic Nature of Miracles"]. Collectanea Theologica 57, no 4 (1987): 39-54.

RUSECKI, Marian. "Teologia cudu" [“Theology of Miracles"]. In Cuda w sprawach kanonizacyjnych [Miracles in Canonization Cases], edited by Wiesław Bar, 11-94. Lublin: Wydawnictwo Diecezjalne w Sandomierzu, 2006.

RusECKI, Marian. “Teologicznofundamentalna myśl Księdza Józefa Kudasiewicza.” In W postudze Stowa Pańskiego. Księga pamiątkowa poświęcona Ks. prof. dr. hab. Józefowi Kudasiewiczowi z okazji 70-lecia urodzin ["The Theological and Fundamentalist Thoughts of Father Józef Kudasiewicz.” In: In the Ministry of the Lord's Word. A Memorial Book Dedicated to Rev. Prof. Józef Kudasiewicz on his $70^{\text {th }}$ Birthday], edited by Stanisław Bielecki, Hubert Ordon, Henryk Witczyk, 23-32. Kielce: Wydawnictwo Jedność, 1997.

RuSECKI, Marian. Traktat o cudzie [Treatise on Miracles]. Lublin: Komitet Nauk Teologicznych PAN-Wydawnictwo KUL, 2006.

RUSECKI, Marian. Traktat o Objawieniu [Treatise on Revelation]. Kraków: Wydawnictwo Księży Sercanów, 2007.

RuSECKI, Marian. Traktat o wiarygodności chrześcijaństwa. Dlaczego wierzyć Chrystusowi? [Treatise on the Credibility of Christianity. Why Should We Believe Christ?]. Lublin: TN KUL, 2010.

RUSECKI, Marian. "Uzasadnianie wiarygodności chrześcijaństwa.” In Ksiadz Profesor Marian Rusecki. Doktor ,honoris causa” Papieskiego Wydziatu Teologicznego we Wroctawiu, 61-76 ["Justifying the Credibility of Christianity." In: Rev. Professor Marian Rusecki. Doctor Honoris Causa of the Pontifical Faculty of Theology in Wroclaw]. Wrocław: Papieski Wydział Teologiczny, 2012.

RUSECKI, Marian. "Wiara i rozum w świetle encykliki Fides et ratio." In Nauka-wiara. Rola filozofii ["Faith and Reason in the Light of the Encyclical Fides et ratio." In: Science-Faith. The Role of Philosophy], edited by Marek Słomka, 109-128. Lublin: Wydawnictwo KUL, 2009.

RUSECKI, Marian. "Wiara jako odpowiedź człowieka na Boże objawienie.” In Katechizm Kościoła Katolickiego. Wprowadzenie ["Faith as Man's Answer to Divine Revelation." In: Catechism of the Catholic Church. Introduction], edited by Marian Rusecki, Edward Pudełko, 43-54. Lublin: RW KUL, 1995.

RUSECKI, Marian. Wiarygodność chrześcijaństwa, vol. 1: Z teorii teologii fundamentalnej [The Credibility of Christianity, vol. 1: From the Theory of Fundamental Theology]. Lublin: TN KUL, 1994.

Rusecki, Marian. "Wiarygodność Kościoła w Polsce jako rzeczywistości personalistycznej i dynamicznej” [,The Church's Credibility in Poland as a Personalistic and Dynamic Reality”]. Studia Warmińskie 30 (1993): 377-390.

RuSECKI, Marian. "Wiarygodność posłannictwa Jezusa Chrystusa.” In Jezus Chrystus jedyny $i$ uniwersalny Zbawiciel. Sympozjum ["Credibility of the Mission of Jesus Christ." In: Jesus 
Christ, the Only and Universal Savior. Symposium], edited by Zbigniew Morawiec, 19-35. Kraków: Wydawnictwo Księży Sercanów, 2001.

RUSECKI, Marian. Wierzcie moim dziełom. Funkcja motywacyjna cudu w teologii XX wieku [Believe in my Works. The Motivational Function of Miracles in the $20^{\text {th }}$ Century Theology]. Katowice: Księgarnia Św. Jacka, 1988.

RUSECKI, Marian. "Współczesne teorie kwestionujące historyczność Jezusa Chrystusa.” In Jezus Chrystus. Ikona historii i wiary ["Contemporary Theories Questioning the Historicity of Jesus Christ.” In: Jesus Christ. An Icon of History and Faith], edited by Ryszard Dziura, 52-61. Lublin: TN KUL, 2004.

Rusecki, Marian. "Za kogo uważał się Jezus? Mesjańska świadomość Jezusa.” In Być chrześcijaninem dziś. Teologia dla szkót średnich ["Who Did Jesus Consider Himself to Be? The Messianic Consciousness of Jesus." In: Being a Christian Today. Theology for Secondary Schools], edited by Marian Rusecki, 146-151. Lublin: RW KUL, 1992.

RUSECKI, Marian. "Zagadnienie personalizmu w pracach badawczych Wydziału Teologii KUL (19681993)" ["The Issue of Personalism in the Research Work of the Faculty of Theology at the Catholic University of Lublin (1968-1993)"]. Roczniki Teologiczne 43, no 4 (1996): 249-263.

RuSECKI, Marian. “Źródła pozachrześcijańskie historyczności Jezusa Chrystusa.” In Jezus Chrystus. Ikona historii i wiary ["Non-Christian Sources of the Historicity of Jesus Christ." In: Jesus Christ. An Icon of History and Faith], edited by Ryszard Dziura, 37-46. Lublin: TN KUL, 2004.

SKIERKOwSKI, Marek. "Krzyż w teologii fundamentalnej. Sprawozdanie ze Zjazdu Teologów Fundamentalnych, Płock-Sikorz, 16-17.04.1998 r." ["The Cross in Fundamental Theology. Report from the Congress of Fundamental Theologians, Płock-Sikorz, April 16-17, 1998"]. Studia Paradyskie 8 (1998): 181-190.

TOMCZAK, Ryszard. "Ewolucja interpretacji funkcji cudów Jezusa w teologii XX wieku w ujęciu M. Ruseckiego.” In Scio Cui credidi. Księga pamiątkowa ku czci Księdza Profesora Mariana Ruseckiego w 65. rocznice urodzin ["The Evolution of the Interpretation of the Miracles of Jesus in $20^{\text {th }}$ Century Theology according to M. Rusecki." In: Scio Cui credidi. A Memorial Book in Honor of Professor Marian Rusecki on his $65^{\text {th }}$ Birthday], edited by Ireneusz S. Ledwoń, Krzysztof Kaucha, Zbigniew Krzyszowski, Jacenty Mastej, Andrzej Pietrzak, 111-122. Lublin: Wydawnictwo KUL, 2007.

Translated by Jan Kobytecki

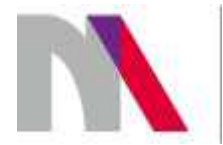

The preparation of the English version of Roczniki Teologiczne (Annals of Theology) and its publication in electronic databases was financed under contract no. 836/P-DUN/2018 from the resources of the Minister of Science and Higher Education for the popularization of science. 